\title{
Trends, Cycles and Seasonal Variations of Ukrainian Gross Domestic Product
}

http://doi.org/ 10.21272/fmir.4(3).80-94.2020

\section{Debesh Bhowmik}

Dr, Former Principal and Associated, Lincoln University College, Malaysia

\begin{abstract}
The article attempts to study trends, seasonal variations and cyclical fluctuations of Ukraine's quarterly GDP at current prices. The period of the study is from the first quarter of 2010 to the first quarter of 2020. The methodological support of the study includes an approach based on the Hamilton regression filter, the HodrickPrescott filter and the asymmetric filter model of Cristiano and Fitzgerald. Based on the use of a Hamilton regression filter, which clearly gives one complete cycle with a peak and a depression, the study substantiates that the seasonally adjusted series of GDP has a slight difference with the remainder, but its seasonal fluctuations are homogeneous and have the shape of the letter $\mathrm{V}$, which allowed us to draw the following conclusions: seasonal fluctuations in GDP are confirmed by the ACF and PACF models during the study period; the filter is very different from the Hamilton filter in terms of trend and cycle, but has common features in the context of asymmetry in time with the random walk filter of Cristiano and Fitzgerald. The paper substantiates the conclusions about stable and stationary series of GDP by volatility (leading to a decrease) of cyclical fluctuations based on the used forecast model ARIMA $(4,0,4)$ for 2020-2030, which passed through the Hamilton regression filter. Based on the results of the study, the author provides recommendations on the need to introduce a new monetary and fiscal policy, including reform measures, which should be balanced with current trends in the functioning and development of international financial institutions and organizations. Such changes will be a motivating lever for the growth of the share of agriculture and related activities, production, transport, real estate, capital formation and other macroeconomic indicators of Ukraine's economy, respectively, during the period of GDP decline.
\end{abstract}

Keywords: Gross Domestic Product, decomposition, trends, cyclical fluctuations, seasonal variations, Hamilton Filter, Hodrick-Prescott Filter.

JEL Classification: C20, C32, E32, E41, N10, O47.

This work is licensed under a Creative Commons Attribution 4.0 International License

Cite as: Bhowmik, D. (2020). Trends, Cycles and Seasonal Variations of Ukrainian Gross Domestic Product. Financial Markets, Institutions and Risks, 4(3), 80-94. http://doi.org/ 10.21272/fmir.4(3).80-94.2020.

(C) The Author, 2020. This article is published with open access at Sumy State University.

\section{Introduction}

The decomposition of macroeconomic time series with trend and cyclical components is crucial to many macroeconomic concepts such as potential output, natural interest rate, share prices and inflation rate and so on. Econometric analysis requires filtering techniques which cater data sequences having short and strong trends. Filter can be used to decompose a time series into trend, seasonal and irregular components. Filter consists of symmetric and asymmetric. Robert Henderson (1916) derived moving average with filters which are of both symmetric or asymmetric. Baxter and King (1999) explained fixed length symmetric filter which can isolate components that have a cyclical duration of no less than six quarters and of no more than 32 quarters. The model sought to fulfil their requirement in a band pass filter that should ideally have instantaneous transitions at two frequency values. While Christiano and Fitzgerald (2003) explained both the symmetric and asymmetric filter with stationary and nonstationary processes. It can fit a process embodying a first order random walk and attributable to a single unit root within an autoregressive operator. Even it may be appropriate to extrapolate the data at the levels of the end points. Many business cycles analysis, volatility of stock price indices and unemployment trends and cyclical patterns have been being studied through Baxter and King (1999) and Christiano and Fitzgerald (2003) models till now. 
The analysis of spectral density of the ARMA (p, d, q) process shows the fluctuations of a series where spectra density function is expected value of a periodogram or autocovariance which means a graph of the spectra density or conversely, the periodogram can be used as an estimator of the spectra density. The spectra density function of a time series data shows amplitudes of oscillatory signals. It has many limitations to clarify the trends and cyclical behaviour especially business cycle fluctuations.

Band pass filter can develop a multivariate filter which is an optimal approximation to the ideal filter that isolates a specified range of fluctuations in a time series. Band pass filters are useful in measuring the business cycle components of macroeconomic activities. It can eliminate quadratic deterministic trends from a time series. High pass and band pass filters are easily constructed from low pass filters. The ideal high pass filter passes components of the data with periodicity less than or equal to $\mathrm{p}=32$.A low pass filter removes high frequency cycles while retaining low ones. The high pass filter does the reverse task. A band pass filter can be applied through autoregressive process also. Business cycles volatility can be easily measured by band pass filter with $\mathrm{k}=20$.Hodrick-Prescott filter (1997) with $\lambda=1600$ in quarterly data produces a reasonable approximation to a high pass filter. On the other hand, assuming $\lambda=100$, H.P. filter is considered as band pass filter where components of data with cycles between 9 to 16 years. Presently, H.P. filter model is widely used in order to justify smooth cyclical trend and the nature of cycle in the fields of employment, output, income, share prices, inflation and macro-economic variables in spite of some limitations.

Hamilton (2018) criticised Hodrick-Prescott filter model because of its formulations and barriers and proposed a regression filter model which decomposed trend, cycle and seasonal variation of a time series. Hamilton filter as an alternative to Hodrick-Prescott high pass-filter was utilised by Diallo (2018) and remarked that it is a superior alternative. Very recently, Hodrick (2020) modified the analysis of decomposition and applied ARIMA model in the GDP series of USA to explain the trends and cycles. Now-a-days, many comparative studies between H.P. Filter and Hamilton filter in explaining the nature of cycles in purely econometrics fields are fully available for research works. In this case, Hamilton filter could be used in ARIMA (p, d, q) forecasting model to get tendency of future volatility of stock prices, trade cycles, fluctuations of unemployment and cycle of GDP respectively that might help the policy areas of the selected variables.

Ukraine has been separated from USSR since the collapse of socialism in USSR and since then it had been confronting with series of reform processes for reconstruction and rebuilding of the economy especially in the fields of industry, agriculture, trade and international finance and tourism respectively. It introduced managed floating exchange rate mechanism for Hryvnia with US dollar which produced shock from inflation and depreciation so that BOP deficits created high demand for foreign exchanges as an impact of high debt. By adopting inflation and unemployment restraining measures, Ukraine could not avoid negative inflation growth trade off in spite of several advantages of currency board adjustment (Tkalenko \& Glushchenko,2016). Even, it has been facing adverse economic impact due to devastation in Donbas and from brutal adverse consequences of financial crisis in 2008 and recession in Greece. Irrespective of these adverse effects, Ukrainian economy grew steadily towards upward trend although it had been experiencing downfall of GDP in every first quarter of the year successively as a seasonal effect and including other political and economic reasons.

In general, Greek recession during 2011-12 induced economy of Ukraine massively which had negative impact on GDP significantly. In 2013, Russia imposed custom control that affected export inversely. In 2014, Ukraine confronted with great loss of GDP due to war in Donbas. Moreover, the currency Hryvnia of Ukraine faced depreciation against US\$ when enters into managed floating exchange rate system during 2014-19. The Hryvnia has appreciated in spring and depreciated in autumn of each of the past three years. Broadly, problem of unemployment, inflation, public debt, lowering agricultural share to GDP, slowing manufacturing share, and low human capital growth rate helped to sustain cyclical fluctuation of Ukrainian GDP as well. All of these economic and political reasons including poverty, regional disparity, problem of migration, misalignment in the process of liberalisation and globalisation including cold winter season's deceleration compelled Ukrainian economy to pass through the cyclical fashion in GDP during the entire course of smooth upward cyclical trend other than the successive declines of GDP in the first quarters.

Therefore, the paper seeks to derive both H.P. Filter and Hamilton filter in the GDP of Ukraine at current prices using quarterly data series from 2010Q1 to 2020Q1 in order to decompose trend, cycle and seasonal variations to analyse the comparisons with each other including economic implications. Moreover, the paper applies ARIMA ( $p, d, q)$ model in the Hamilton filter to forecast Ukrainian GDP for the year 2030.How much this study is helpful to provide the concept of economic reasons of downfall of GDP when it is analysed from the 
observations of the models, have been also scrutinised. This paper also suggested some economic policies and reform measures in the sectors in which seasonal variations had been occurring each year.

\section{Some important researches}

Some relevant important literatures which reflected cyclical nature of macro-economic variables including GDP of Ukraine or any other country have been incorporated here. Burns and Mitchell (1946) explained that the business cycles are a type of fluctuation of a country's overall economic activity and can be defined as the dynamics of main macroeconomic indicators. It consists of four phases: peak, recession, trough and recovery which are repeated constantly but not periodically. The duration of a cycle ranges from one to ten or twelve years. The recession and recovery are the turning points of a cycle and they are different from each other in time and intensity but they have all same phases.

Prescott (1986) argues that attention should be focused not on fluctuations in output rather on determinants of the average rate of technological advance since theory predicts fluctuations in output of 5\% and more from trend, with most of the fluctuation accounted for by variations in employment and virtually all the rest by the stochastic technology parameter. Hamilton (1989) developed a non-linear iterative filter based on an algorithm that is able to explain regime shifts in the growth rate which are mimic business cyclical fluctuations. This methodology distinguishes itself from a rather arbitrary technique by specifying the turning point as a structural event that is inherent to the data generating process. Cleveland et al(1990) computed Seasonal Trend Decomposition using Loess(STL) filter technique to decompose a seasonal time series into three components namely trend, seasonal, and remainder in which it has a simple design that consists of a sequence of applications of the Loess smoother, the simplicity allows analysis of the properties of the procedure and allows fast computation, even for very long time series and large amounts of trend and seasonal smoothing. Dolado et al (1993) studied the economy of Spain on GDP during 1970-1990 to characterise the business cycle patterns describing the volatility of the real and nominal variables, their intensity and their co-movements with output and prices and to compare regularities with OECD countries. Authors found that volatility seems to be lower in output compared with OECD and higher in consumption, government spending, employment and in terms of trade. However, it is lower in productivity. Secondly, exports are countercyclical. Money is procyclical. Prices are countercyclical and there is a negative relation between money and prices. Money velocity is countercyclical. Terms of trade and nominal exchange rate are procyclical. Thirdly, it was observed a substantial reduction in output volatility as well as in the rest of the demand components. There are lower volatilities in money, prices and velocity and terms of trade. Gali (1999) emphasised that technology shocks which act as an impulse are necessary and proved that technological shocks have a positive effect on the labour market in the long run. Baxter and King (1999) proposed band-pass filter approach which decomposes series with trend, cycle and irregular components to the low, intermediate and high frequency parts of the spectrum which can isolate the components of the fluctuations between 6, and 32 quarters and removes the components of higher and lower frequencies as non-cyclical. Bjomland (2000) used quarterly data of Norway during 19711989 and 1978-1993 for consumption, investment and productivity to estimate trends, structural breaks and cycles and observed that business cycles in those variables are positively correlated with the business cycle in GDP. Traditional real wage and CPI showed both a procyclical and a countercyclical pattern depending on the decomposition method used. According to Zarnowitz and Ozyildirim (2002), a trend is a long run tendency in economic time series which may consists of variability of short run or medium-term cyclical, seasonal and irregular components which are difficult to explain. Economies grow through cycles of expansions and contractions that vary widely in amplitude and duration. Generally, technological innovations speed up growth temporarily disruptions of supply or demand in times of war, civil conflict or industrial dispute deter growth temporarily. The monetary and exchange regimes differ, periods of inflation and deflation have historically alternated where trends may be smooth but they vary and change. Toledo (2004) compared H.P. Filter and band-pass filter in applying Brazilian data and showed that H.P. Filter is qualitatively inferior to the band-pass filter in extracting Brazilian business cycles. Yogo (2008) applied wavelet filters to extract business cycles from time series data in which the technique can only capture periodicities of a power of two i.e. 2,4,8,16,32 and so on not in a full freedom since the upper bound of the cycle periods is equal in both and the lower bound differs only by two- $2^{3}=8$ compared to 6 in the Baxter-King Filter. Using Beveridge and Nelson and SVAR models, Liu (2008) investigated the business cycle fluctuations for the Australian economy taking data of GDP during 1980Q1-2006Q1 and found that international factors account for over half the domestic fluctuations while demand type shocks play a small role. Dias and Dias (2010) account for the trend, cyclical and error or 
irregular components of Brazilian real GDP during 1977Q1-1994Q4 using ARIMA model. Brazilian real cycle had two distinct periods, i.e. 1980-1994 in which time short factors were the dominant aspect which causes unstable business cycle and from 1995 onward where short run factors were minimised and long run factors predominated and the business cycle became less volatile. Zalgiryte and Giziena (2014) used quarterly GDP data of Estonia, Lithuania and Latvia during 1955Q2-2013Q3 applying mth degree polynomial function and found that seasonally adjusted GDP changes move to have similar distribution for Estonia and Lithuania showing more years with medium growth compared in Latvia. Cyclical behaviour of seasonally adjusted GDP changes tends to have similar trends for three countries. Cyclical patterns of seasonally adjusted GDP changes for Estonia and Latvia tend to be more congruent. Hamilton Filter (2018) claims that H.P. Filter creates spurious dynamic relation, fails to eliminate spurious predictability, produces values for the smoothing parameter vastly at odds with common practice. It is not also a sensible approach for a random walk. Therefore, author uses regression variable at date $t+h$ on the four most recent values as of date $t$ which is a better alternative to detrend and to extract cyclical components. Hamilton also assumes random walk, then cyclical component is estimated as $y_{t+h}-y_{t}$ which is predictable and perform much better than the H.P. Filter model. Pollock (2018) opined that filter should be designed with reference to their frequency responses where they should be implemented in the frequency domain in which data should be free of trend that will be able to alleviate the end -of-sample problems. Schuler (2018) applied Hamilton filter in the credit to GDP gap in USA taking data of GDP from Fred during 1947Q1-2017Q1 and data of credit GDP ratio from BIS during 1952Q1-2016Q4 which produced more robust cycle estimates than H.P. filter. Colak, Guney, Senol and Yilmaz (2019) applied Hamilton Filter model with other filters like H.P. Filter, Butterworth filter, Christiano-Fitzgerald filter to construct indicators to determine the episodes of moderate to expensive credit slowdown and expansion during 2007-2019 in Turkish banking sector. Bosupeng (2019) applied both H.P. Filter and Hamilton Filter to compare the application in tourism demand and determined the variability of H.P. Filter in forecasting tourism demand and studied feasibility in investigating trend analysis of tourism demand especially by Hamilton filter. Bhowmik (2020) examined GDP growth rate of India taking quarterly data from 2011Q4-2019Q4 and showed that H.P. Filter trend is upward humped but cyclical pattern have 10 peaks and troughs. Hamilton regression is insignificant but seasonally adjusted and actual series have been merged since data are seasonally adjusted but cyclical trend is very much prominent with three peaks and troughs. There is a sharp difference of cyclical trend in H.P. Filter and Hamilton Filter models but seasonal adjustments are identical. Hamilton Filter produces clear seasonal variation showing $\mathrm{v}$ shaped volatility and cycles confirmed two peaks. ACF and PACF of Hamilton residual series verified the nature of seasonality. Residuals suffer from the problem of heteroscedasticity. ARIMA $(1,0,0)$ process of Hamilton filter for forecasting 2030 converges to stable and stationary processes.

\section{Methodology and sources of data}

Given $T$ observations on a variable $\mathrm{x}_{\mathrm{t}}$, Hodrick-Prescott Filter model (1997) proposed interpreting the trend component $\mathrm{g}_{\mathrm{t}}$ as a very smooth series that does not differ too much from the observed $\mathrm{x}_{\mathrm{t}}$. It is calculated as:

$1 / \mathrm{T}\left\{\Sigma\left(\mathrm{x}_{\mathrm{t}}-\mathrm{g}_{\mathrm{t}}\right)^{2}+\lambda / \mathrm{T} \Sigma\left[\left(\mathrm{g}_{\mathrm{t}}-\mathrm{g}_{\mathrm{t}-1}\right)-\left(\mathrm{g}_{\mathrm{t}-1}-\mathrm{g}_{\mathrm{t}-2}\right)\right]^{2}\right\}$ where $\Sigma \mathrm{t}=1$ to $\mathrm{T}, \mathrm{T}=$ observations, $\lambda=$ constant and minimise $\left(\mathrm{g}_{\mathrm{t}}\right)$ from $\mathrm{t}=-1$ to $\mathrm{T}$.

When the smoothness penalty $\lambda$ tends to zero, $g_{t}$ will just be the series $x_{t}$ itself, whereas when $\lambda$ tends to infinity, the procedure amounts to a regression on a linear time trend (i.e. produces a series whose second difference is exactly zero). The common practice is to use a value $\lambda=14400$ for monthly data.

The solution is given by $\mathrm{g}^{*}=\left(\mathrm{H}^{\prime} \mathrm{H}+\lambda \mathrm{Q}^{\prime} \mathrm{Q}\right)^{-1} \mathrm{H}^{\prime} \mathrm{x}=\mathrm{A}^{*} \mathrm{x}$

The inferred trend $\mathrm{g}_{\mathrm{t}}$ for any date $\mathrm{t}$ is thus a linear function of the full set of observations on $\mathrm{x}_{\mathrm{t}}$ for all the dates.

Where the vector $\left.\mathrm{H}(\mathrm{TxT})=\left[\mathrm{I}_{\mathrm{T}}(\mathrm{TxT})\right) 0(\mathrm{Tx} 2)\right]$ and the matrix $\mathrm{Q}(\mathrm{TxT})$ is given by:

\begin{tabular}{|c|c|}
\hline $1-210$ & 000 \\
\hline $01-21$ & 000 \\
\hline 0000 & -210 \\
\hline 0000 & $1-21$ \\
\hline
\end{tabular}

Hamilton (2018) regression filter model is expressed in the following manner for quarterly data. 


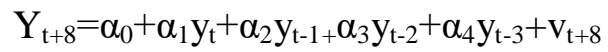

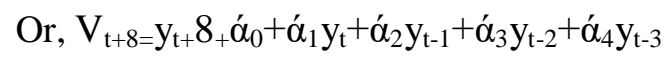

where $\mathrm{V}_{\mathrm{t}}+8$ and $\dot{\alpha}_{0}, \dot{\alpha}_{1}, \dot{\alpha}_{2}, \dot{\alpha}_{3}+\dot{\alpha}_{4}$ are estimated values

So, $\mathrm{y}_{\mathrm{t}}=\alpha_{0}+\alpha_{1} \mathrm{y}_{\mathrm{t}-8}+\alpha_{2} \mathrm{y}_{\mathrm{t}-9+} \alpha_{3} \mathrm{y}_{\mathrm{t}-10}+\alpha_{4} \mathrm{y}_{\mathrm{t}-11}+\mathrm{v}_{\mathrm{t}}$

Therefore, $\mathrm{t}=\mathrm{y}_{\mathrm{t}}-\left(\dot{\alpha}_{0}+\dot{\alpha}_{1} \mathrm{y}_{\mathrm{t}-8}+\dot{\alpha}_{2} \mathrm{y}_{\mathrm{t}-9}+\dot{\alpha}_{3} \mathrm{y}_{\mathrm{t}-10}+\dot{\alpha}_{4} \mathrm{y}_{\mathrm{t}-11}\right)$ where $\dot{\alpha}_{\mathrm{i}}$ are estimated.

$\mathrm{V}_{\mathrm{t}+\mathrm{h}}=\mathrm{y}_{\mathrm{t}+\mathrm{h}}-\mathrm{y}_{\mathrm{t}}$ is the difference i.e. how the series changes over $\mathrm{h}$ periods. For $\mathrm{h}=8$, the filter 1- $\mathrm{L}^{\mathrm{h}}$ wipes out any cycle with frequencies exactly one year and thus taking out both long run trend as well as any strictly seasonal components.

It also applies random walk: $\mathrm{y}_{\mathrm{t}}=\mathrm{y}_{\mathrm{t}-1-\varepsilon_{\mathrm{t}}}$ where $\mathrm{d}=1$ and $\omega_{\mathrm{t}}^{\mathrm{h}}=\varepsilon_{\mathrm{t}+\mathrm{h}}+\varepsilon_{\mathrm{t}+\mathrm{h}-1}+\ldots \ldots \ldots \ldots+\varepsilon_{\mathrm{t}+1}$

Regression filter reduces to a difference filter when applied to a random walk. Hamilton suggested $\mathrm{h}=8$ for business cycles and $\mathrm{h}=20$ for studies in financial cycles. Regression $t$ converges in large samples to $\alpha_{1}=1$ and all other $\alpha_{\mathrm{j}}=0$. Thus, the forecast error is $\mathrm{v}_{\mathrm{t}+\mathrm{h}}=\mathrm{y}_{\mathrm{t}+\mathrm{h}}-\mathrm{y}_{\mathrm{t}}$.

The equation $t$ can be decomposed into trend, cycle and seasonally adjusted through SEATS/TRAMO or STL or census X-13 packages. Even it can be used for ARIMA (p, d, q) model for forecasting at date. The paper applied Box-Jenkins (1976) methodology for forecasting in 2030 of ARIMA (p, d, q) by incorporating in the Hamilton regression filter equation and the paper also used Bai-Perron (2003) model to find structural breaks of GDP of Ukraine.

Quarterly data of Ukraine's GDP from 2010Q1 to 2020 Q1 at current prices have been collected from ukrstat.gov.ua/imf/arhiv/nr/nr_u.htm

\section{The major findings of the econometric models}

3.1. Linear trends and structural breaks of GDP. The linear trend line of GDP of Ukraine has been estimated below which states that GDP of Ukraine has been increasing at the rate of 3.66\% per quarter from $2010 \mathrm{Q} 1$ to 2020Q1 which is statistically significant at 5\% level.

$\log (\mathrm{y})=12.3437+0.03667 \mathrm{t}$

$$
(279.34) *(20.00)^{*}
$$

$\mathrm{R}^{2}=0.911, \mathrm{~F}=400.208^{*}, \mathrm{DW}=1.43, \mathrm{AIC}=-1.062, \mathrm{SC}=-0.979, \mathrm{y}=\mathrm{GDP}$ at current prices in million $\mathrm{UAH}, \mathrm{t}=$ period, $\mathrm{n}=41, *$ =significant at $5 \%$ level

The linear trend line of GDP is shown in Figure 1 where the fitted trend line is rising upward steadily and the actual GDP of Ukraine is growing with upswings and downswings like an inverse $\mathrm{v}$ shaped.

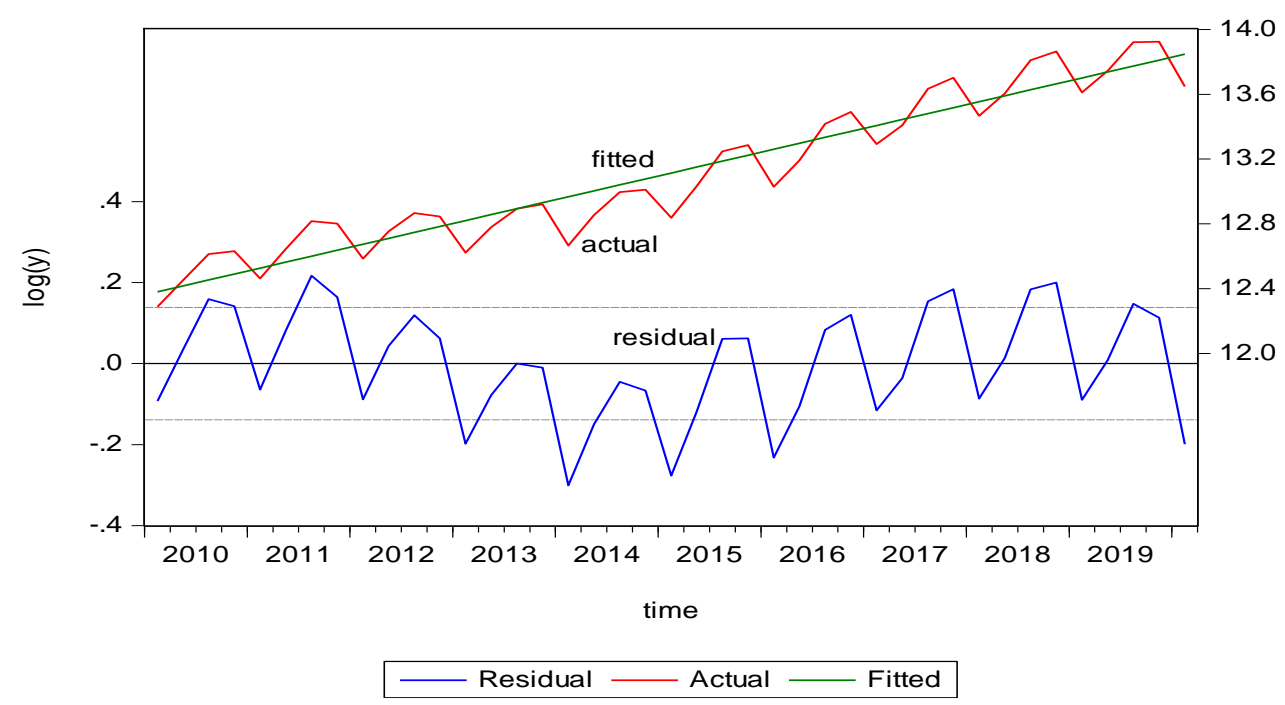

Figure 1. Linear trend of GDP

Source: Compiled by author. 
The stability test of the estimated trend line was observed as stable with significantly $5 \%$ level according to CUSUM of squares during the specified period which is depicted in Figure 2 where the line of CUSUM of squares lie within the significant level.

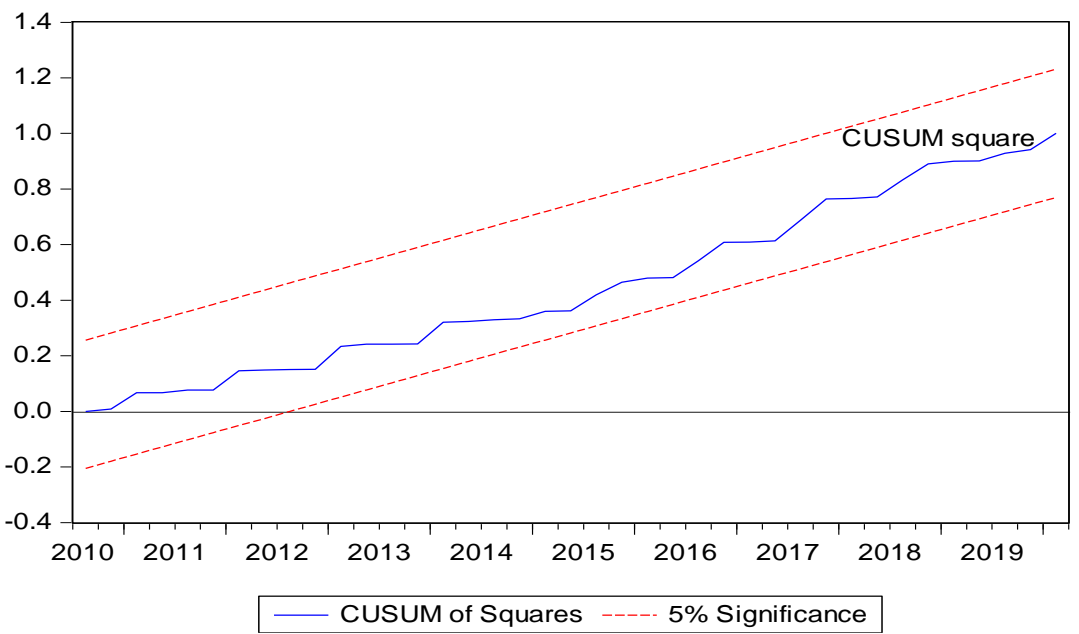

Figure 2. Stability test of trend line

Source: Compiled by author.

Bai-Perron (2003) model is applied to find structural breaks of quarterly GDP of Ukraine from 2010Q1 to 2020Q1 where HAC standard errors \& covariance is assumed taking Bartlett kernel, and Newey-West fixed model with bandwidth $=4.0000$ in which the models are restricted to take maximum 5 breaks selecting Trimming 0.15 at $5 \%$ significant level and it is also assumed that $\mathrm{L}+1$ vs. L sequentially determined breaks is the type of break. The model revealed that there were 4 upward structural breaks which were appeared during 2011Q3, 2013Q3, 2015Q3, and 2017Q3 respectively showing coefficients, standard errors, t statistic and probabilities. The estimated model is highly significant with high $\mathrm{R}^{2}$ and D.W. (Table 1).

Table 1. Structural breaks of GDP of Ukraine

\begin{tabular}{|c|c|c|c|c|}
\hline Variable & Coefficient & Standard Error & t-Statistic & Probability \\
\hline & & 2010Q1 - 2011Q2 -- 6 obs. & & \\
\hline \multirow[t]{2}{*}{$\mathrm{C}$} & 12.51544 & 0.051526 & 242.8940 & 0.0000 \\
\hline & & 2011Q3 - 2013Q2 -- 8 obs. & & \\
\hline \multirow[t]{2}{*}{$\mathrm{C}$} & 12.75907 & 0.014859 & 858.6994 & 0.0000 \\
\hline & & 2013Q3 - 2015Q2 -- 8 obs. & & \\
\hline \multirow[t]{2}{*}{$\mathrm{C}$} & 12.90134 & 0.035991 & 358.4579 & 0.0000 \\
\hline & & 2015Q3 - 2017Q2 -- 8 obs. & & \\
\hline \multirow[t]{2}{*}{$\mathrm{C}$} & 13.29528 & 0.056058 & 237.1682 & 0.0000 \\
\hline & & 2017Q3 - 2020Q1 -- 11 obs. & & \\
\hline $\mathrm{C}$ & 13.72116 & 0.046851 & 292.8662 & 0.0000 \\
\hline
\end{tabular}

$\mathrm{R}^{2}=0.924, \mathrm{~F}=110.98 *, \mathrm{AIC}=-1.085, \mathrm{SC}=-0.876, \mathrm{DW}=1.666, \mathrm{n}=41, *=$ significant at $5 \%$ level

Source: Calculated by author.

In Figure 3, these structural breaks have been depicted where upward breaks in 2011Q3, 2013Q3, 2015Q3, and 2017Q3 were demarcated clearly with the fitted and actual series of GDP. Since, the trend line of GDP is significantly upward rising during the survey period then in every third quarter of GDP of two years interval there is an upward structural shift due to increase in the fixed coefficient. In other words, an improvement in economic resource allocation had occurred in several sectors that catapulted upward shift of GDP to confront with downward seasonal movement of GDP which is seen during the snowy winter season and that is basically structural property of Ukraine. 


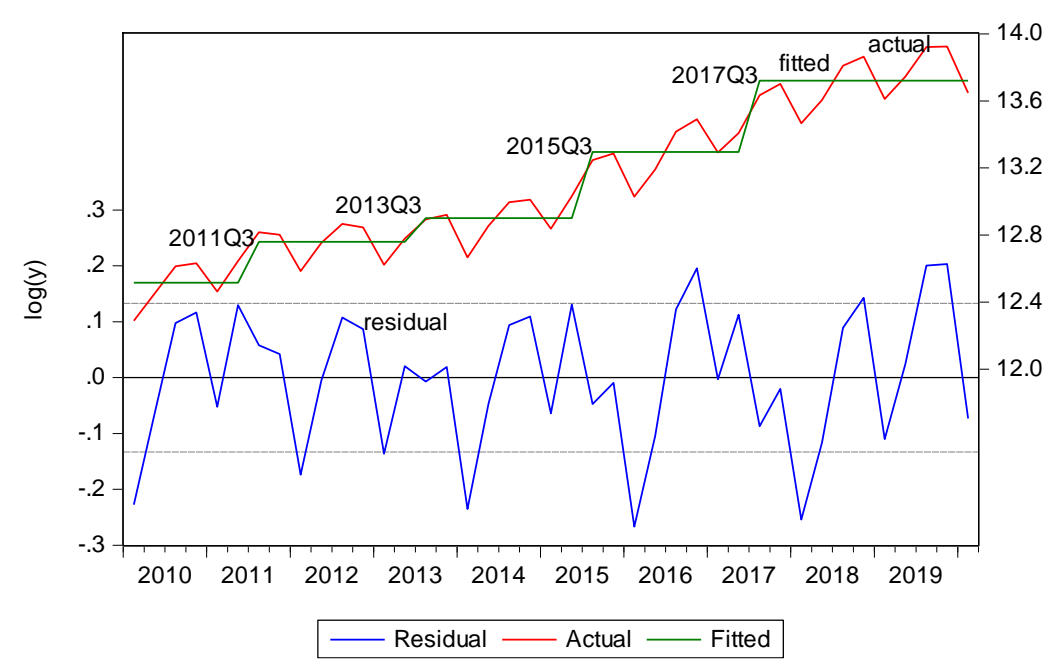

Figure 3. Structural breaks

Source: Compiled by author.

3.2. Decomposition of trends, cycles and seasonal variations. The equation of Hamilton regression filter is found from the estimated equation given below where the coefficient of $\log _{\mathrm{t}-8}$ is significant at $5 \%$ level but other coefficients are insignificant although $\mathrm{R}^{2}$ is very high, $\mathrm{F}$ is significant, SC and AIC are low but DW revealed the existence of autocorrelation. The equation $t$ is called the Hamilton filter residual equation from which the decompositions can be calculated.

$\log \left(\mathrm{y}_{\mathrm{t}}\right)=-1.8158+1.0911 \log _{\mathrm{t}-8}+0.01216 \log \mathrm{y}_{\mathrm{t}-9}+0.0263 \log _{\mathrm{t}-10}+0.0324 \log \mathrm{y}_{\mathrm{t}-11}+\mathrm{v}_{\mathrm{t}}$

$$
(-1.81)(5.44)^{*} \quad(0.055) \quad(0.117) \quad(0.153)
$$

$\mathrm{R}^{2}=0.917, \mathrm{~F}=69.296^{*}, \mathrm{AIC}=-1.19, \mathrm{SC}=-0.958, \mathrm{DW}=0.178, *=$ significant at $5 \%$ level, $\mathrm{n}=30$ after adjustment.

Thus, the residual $\mathrm{v}_{\mathrm{t}}$ becomes

$\mathrm{v}_{\mathrm{t}}=\log \left(\mathrm{y}_{\mathrm{t}}\right)-\left[-1.8158+1.0911 \log \mathrm{y}_{\mathrm{t}-8}+0.01216 \log \mathrm{y}_{\mathrm{t}-9}+0.0263 \log _{\mathrm{t}-10}+0.0324 \log \mathrm{y}_{\mathrm{t}-11}\right]$

In a group diagram in Figure 4, the Hamilton regression filter, its seasonally adjusted line, seasonally adjusted forecast line and the cyclical trend have been plotted very clearly where the trend consists of trough and peak in one cycle but the actual/residual GDP variation is marginally similar with the seasonally adjusted line showing many peaks and troughs. The seasonally adjusted forecast GDP line of Ukraine is as like as v shaped throughout the period and is moving around towards equilibrium.

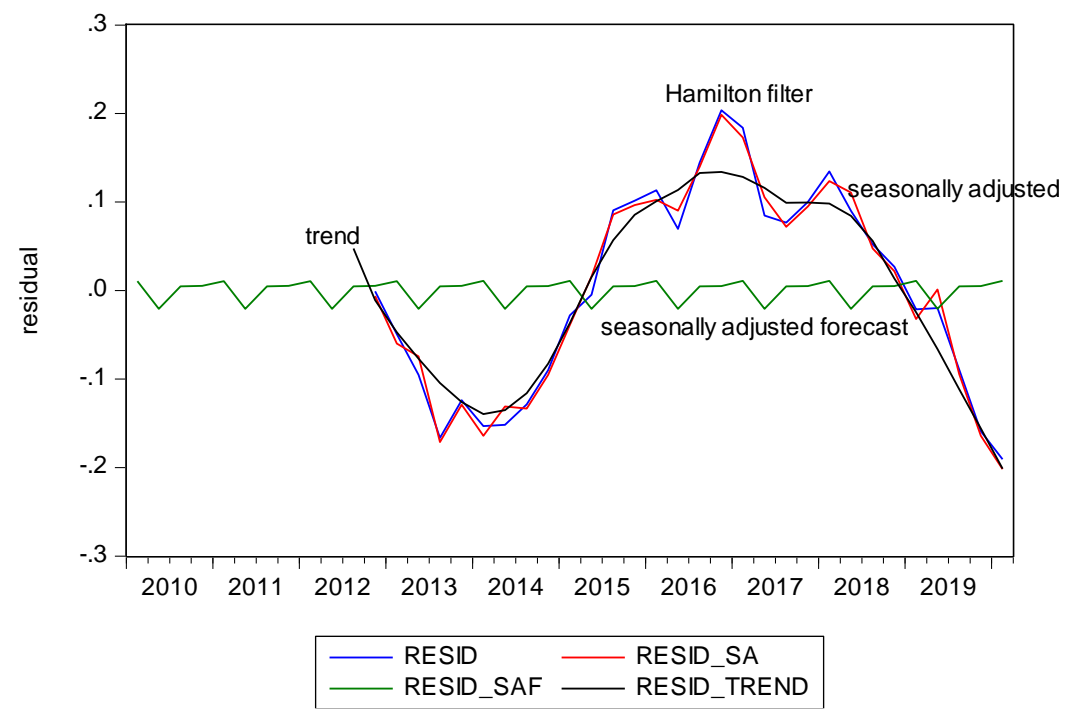

Figure 4. Hamilton filter of GDP of Ukraine

Source: Compiled by author. 
In Figure 5, the Hamilton regression filter residual series has been decomposed into cycle, cyclical trend, seasonal variation, remainder, and seasonally adjusted series respectively in the panel of diagrams. In panel 1, the regression filter or residual series is showing 4 troughs and five peaks with slow revival and recession. In panel 2, the smooth cyclical trend is comprising only one cycle having peak and trough in which recession, trough, revival, peak and again a long recessionary trend were observed. In panel 3, Ukrainian quarterly GDP is uniquely revealing uniform seasonal variation from 2010Q1 to 2020Q1 which have been as like as v shaped. Because, in every first quarter of each year the GDP of Ukraine had fallen and afterwards it had risen for next three quarters uniformly. In panel 4, the remainder series of Hamilton filter consists of 8 peaks and 9 troughs having two spikes with continuous volatility. In panel 5, the seasonally adjusted cycle is shown which is more or less similar with the residual series.
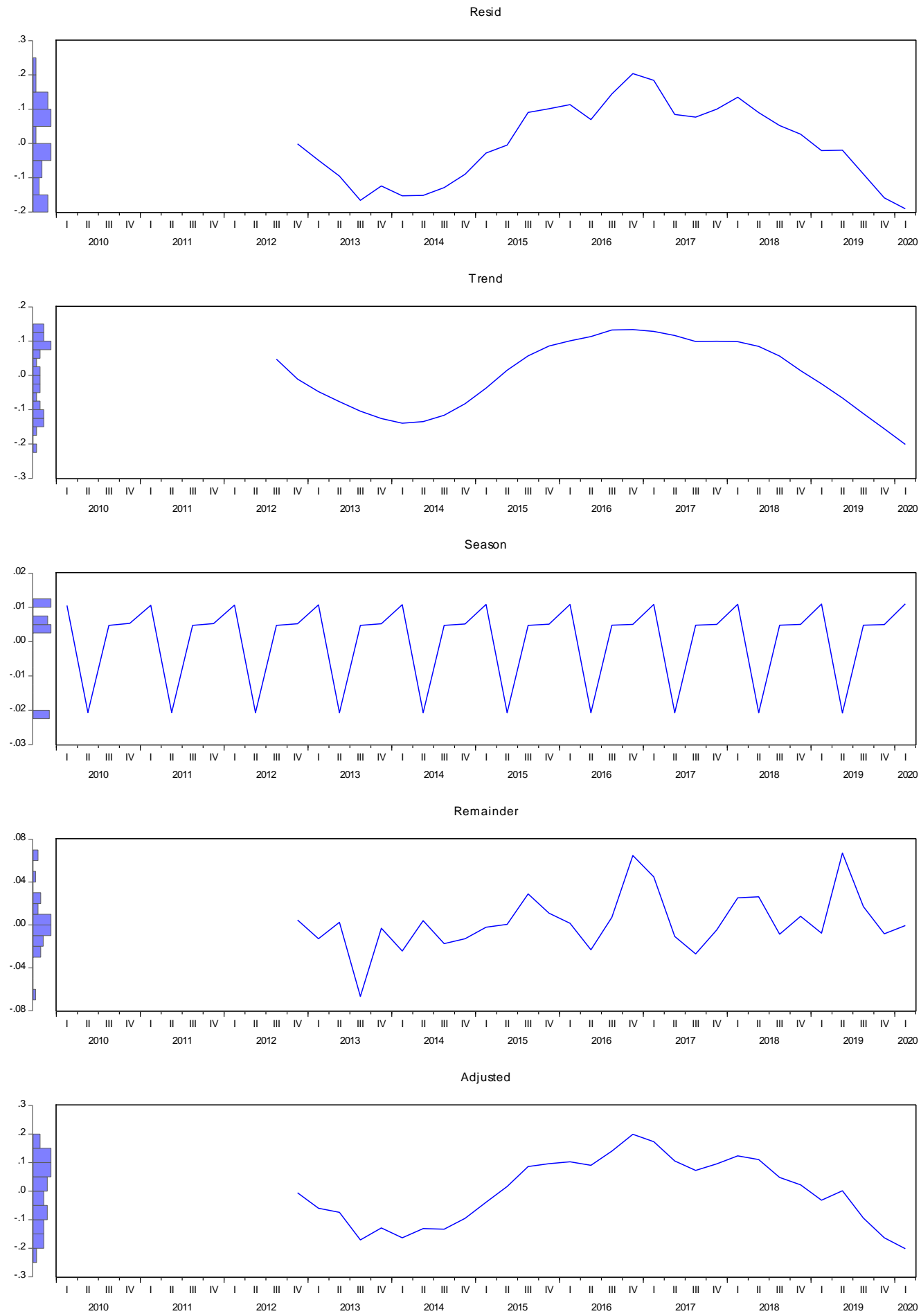

Figure 5. The decomposition of Hamilton filter

Source: Compiled by author. 
The characteristic of seasonal variation of quarterly GDP of Ukraine from 2010Q1 to 2020Q1 has been confirmed by calculating autocorrelation and partial autocorrelation functions where ACF and PACF showed declining and rising patterns in both positive and negative signs where ACF at lag 7 showed negative and started to increase its values up to lag 12 and then declined and all the PACF varied from positive to negative values with one spike at lag 1 which is beyond significant level. However, Q statistic and their probabilities are significant at 5\% level. $(n=30)$. All these behaviours of ACF and PACF had justified the seasonal patterns of Ukrainian GDP. This is shown in Figure 6.

\begin{tabular}{|c|c|c|c|c|c|c|c|c|}
\hline \multicolumn{2}{|c|}{ Autocorrelation } & \multicolumn{2}{|c|}{ Partial Correlation } & \multicolumn{2}{|r|}{$\mathrm{AC}$} & \multirow{2}{*}{$\begin{array}{l}\text { PAC } \\
0.863\end{array}$} & \multirow{2}{*}{$\begin{array}{l}\text { Q-Stat } \\
24.674\end{array}$} & \multirow{2}{*}{$\frac{\text { Prob }}{0.000}$} \\
\hline 1 & & 1 & & 1 & 0.863 & & & \\
\hline 1 & & $1 \sqsubset$ & 1 & 2 & 0.687 & -0.231 & 40.834 & 0.000 \\
\hline 1 & $\square$ & 1 & 1 & 3 & 0.527 & -0.015 & 50.696 & 0.000 \\
\hline 1 & $\square$ & 1 & 1 & 4 & 0.411 & 0.056 & 56.925 & 0.000 \\
\hline & $\sqsupset$ । & $\square$ & 1 & 5 & 0.236 & -0.374 & 59.063 & 0.000 \\
\hline 1 & 1 & 1 미 & 1 & 6 & 0.041 & -0.132 & 59.131 & 0.000 \\
\hline & 1 & 10 & 1 & 7 & -0.132 & -0.070 & 59.862 & 0.000 \\
\hline $1 \square$ & I & 14 & 1 & 8 & -0.258 & -0.101 & 62.764 & 0.000 \\
\hline & 1 & 1 & 1 & 9 & -0.324 & 0.121 & 67.564 & 0.000 \\
\hline ᄃ & 1 & 1 口 & 1 & 10 & -0.396 & -0.187 & 75.073 & 0.000 \\
\hline & 1 & 1 단 & 1 & 11 & -0.464 & -0.107 & 85.939 & 0.000 \\
\hline & 1 & $1 \square$ & 1 & 12 & -0.530 & -0.149 & 100.91 & 0.000 \\
\hline & 1 & 10 & 1 & 13 & -0.514 & 0.061 & 115.83 & 0.000 \\
\hline$\sqsubset$ & 1 & 1 & 1 & 14 & -0.456 & 0.018 & 128.32 & 0.000 \\
\hline & 1 & 11 & 1 & 15 & -0.382 & -0.016 & 137.68 & 0.000 \\
\hline$\square$ & I & 10 & 1 & 16 & -0.343 & -0.116 & 145.74 & 0.000 \\
\hline
\end{tabular}

Figure 6. Confirmation of seasonality

Source: Compiled by author.

According to H.P. Filter model(1997), Lamda is assumed to be 1600 because of quarterly data of Ukrainian GDP from 2010Q1 to 2020Q1 and the decomposition revealed that the trend line is non-linear with upward rising constantly while the actual GDP behaves with an inverse $\mathrm{v}$ shaped which is reflected from the cyclical pattern of the GDP series. It is found upward, then again upward consecutively and then it tends to downward although the clear cyclical trend was not found in H.P. Filter as like as Hamilton filter model since cyclical patterns are inverse $\mathrm{v}$ shaped where in Hamilton model the cyclical trend generated a complete cycle with one peak and trough including recessionary and recovery trends respectively(Figure 7).

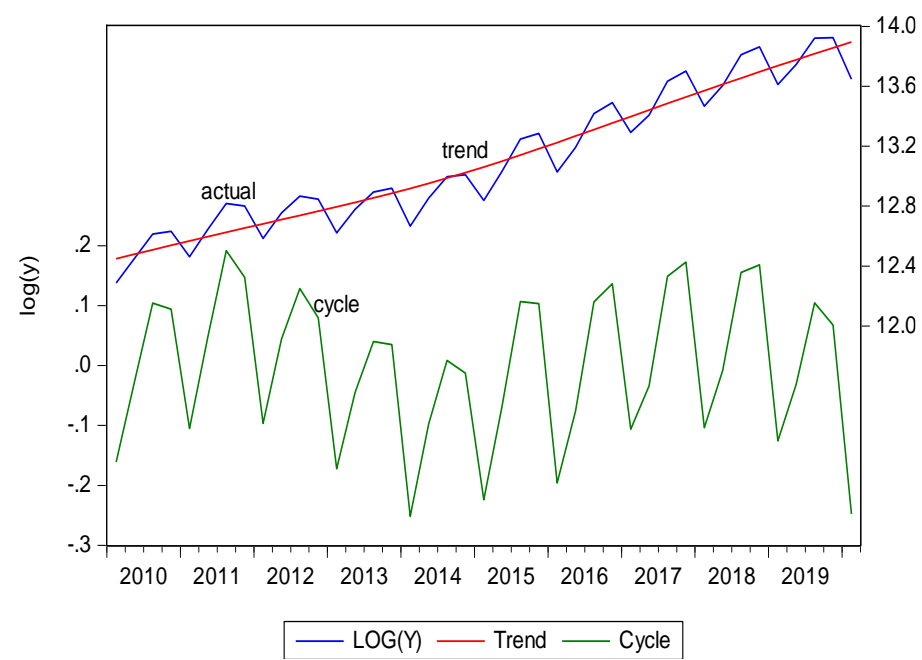

Figure 7. H.P. Filter model

Source: Compiled by author.

If Christiano and Fitzgerald (2003) asymmetric time varying filter with random walk model is taken for decomposition of trends and cycle, then it was found that the cyclical trend is more or less similar with the cyclical trend of Hamilton regression filter. Only difference is that Hamilton cyclical trend started after lag 8 instead of Christiano and Fitzgerald which is shown in Figure 8 where the cyclical trend started with upswing, reached peak 
and then declines for recessionary period very slowly but again reached its peak showing downswing quickly.

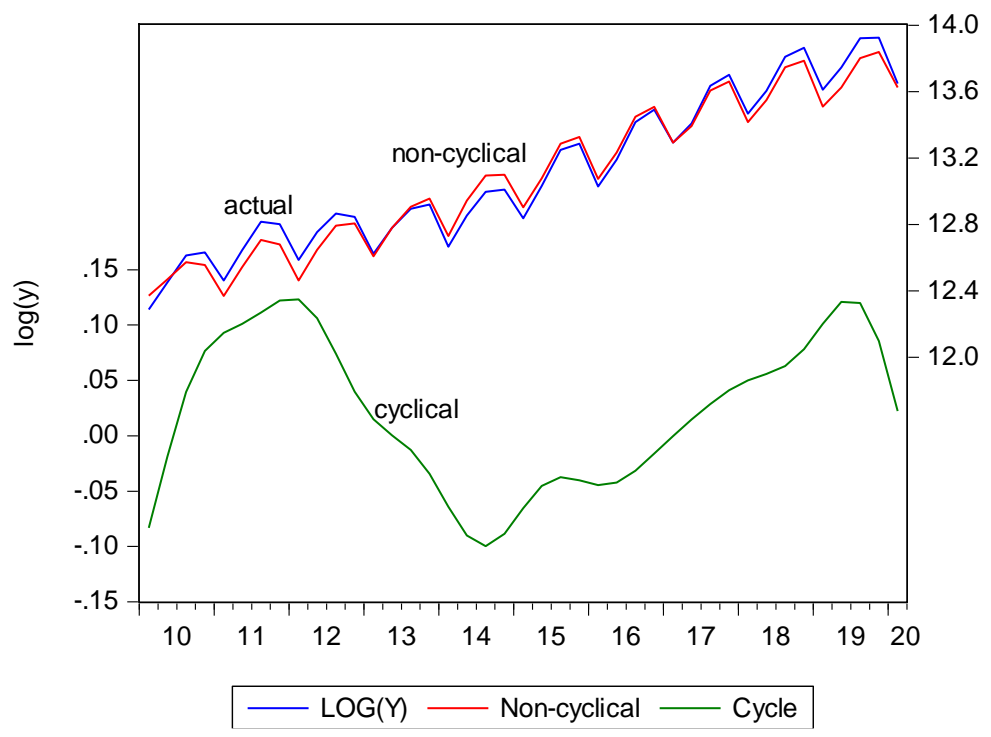

Figure 8. Asymmetric Time varying filter

Source: compiled by author.

It was observed that the extreme cold weather, decelerations of agricultural output, manufacturing contribution, and some service sector contributions during first quarters of each year are the general reasons of seasonal variation of GDP of Ukraine. The cold and snowy weather during January to March slowed down construction works, cargo transportation, wholesale turnover, and supply chain system. This fragile environmental impact amplified the seasonality of GDP in each year. Even, the winter affected negatively to basic household services, increased pressure on high utility cost of finances due to intensifying country's protection activities and also affected negatively on food security index.

These seasonal variations are structural problems of Ukraine which needs anticyclical fiscal and tight monetary policy. Huge investment in infrastructure and foreign inflows will boost to increase in sectoral shares where diversification, technological innovations and environmental protections are needed. Even, changing consumption patterns, new health care system, and increasing human capital formation and improvement in capital market structure might help to catapult value additions in GDP. In addition to that manufacturing share in GDP has declined during 2001-2015, industrial employment decreased and even, the indicator of the share of high technology in the total volume of industrial products decreased from 2001 to 2017(Lebedeva et al,2019).The loss of GDP in Ukraine can be explained by the migrated young labor forces to Poland during 2014-2018 as a result of fall in wages of young work forces in Ukraine and for higher attainment of education in Poland (Strzelecki et al,2020).On the other hand, remittances from Ukrainian immigrants have catapulted financial inflows which improved current account deficits and investment income deficits and also increased VAT, excise and custom revenues(Pieńkowski,2020).

3.3. Forecast analysis of GDP of Ukraine. ARIMA $(4,0,4)$ model is selected from the best 25 models of automatic forecasting technique and if this ARIMA $(4,0,4)$ is passed through the Hamilton regression filter model of the adjusted period from 2012Q4 to 2020Q1 with 30 observations then the estimated model through maximum likelihood becomes as follows.

$\mathrm{y}_{1 \mathrm{t}}=-0.01767+0.2463 \mathrm{y}_{1 \mathrm{t}-4}+\varepsilon_{\mathrm{t}}+0.81778 \varepsilon_{\mathrm{t}-4}+0.0062 \sigma_{\mathrm{t}}^{2}$

$$
(-0.50) \quad(0.89)
$$

$\mathrm{R}^{2}=0.513, \mathrm{~F}=9.13^{*}, \mathrm{DW}=0.258, \mathrm{AIC}=-1.77, \mathrm{SC}=-1.59, \mathrm{n}=30, \mathrm{AR} \quad$ roots $= \pm 0.70,0.00 \pm 0.70 \mathrm{i} \quad$ and $\quad \mathrm{MA}$ roots $=0.67 \pm 0.67 \mathrm{i},-0.67 \pm 0.67 \mathrm{i}$ where $\mathrm{y}_{1}=$ Hamilton filter residual series, ${ }^{*}=$ significant at $5 \%$ level.

This model is a good fit although coefficients of Auto Regression and Moving Average are insignificant but they are positive and less than one which implies that AR and MA are convergent and $t$ value of $\sigma_{t}^{2}$ is highly significant showing minimum volatility and the AIC is the minimum since it is selected. Even, the values of AR and MA roots are all less than one which revealed that the model is stable and stationary. The economic implication is that the first quarter GDP of Ukraine had autocorrelated with fourth quarter of GDP and their 
moving averages are also related but their coefficients became insignificant which implied that convergent processes did not reach towards equilibrium.

This pass-through model has been analysed for forecasting in 2030 which interpreted that the GDP of Ukraine contains two troughs and peaks during the period of forecast and then it converges toward equilibrium reducing volatilities of upswings and downswings steadily. First cycle takes shorter period but the second cycle takes longer time to reach equilibrium point reducing volatilities. It is clearly depicted in Figure 9.

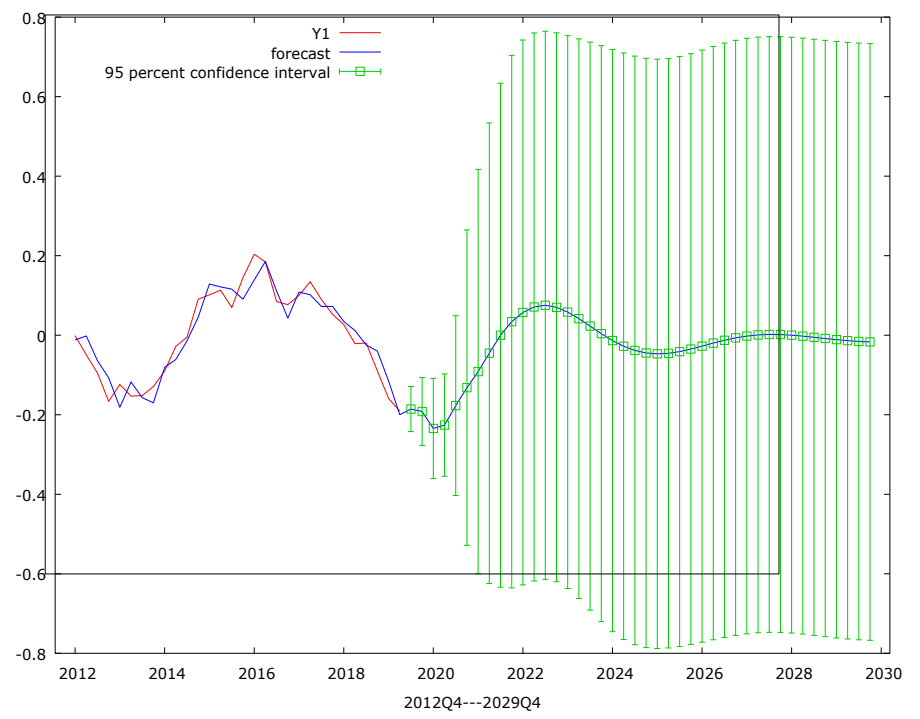

Figure 9. Forecast Hamilton pass through model

Source: compiled by author.

All the AR and MA roots lie inside the unit circle because they are less than one so that the forecasting model is stable and stationary. The unit circle indicating the roots is shown in Figure 10.

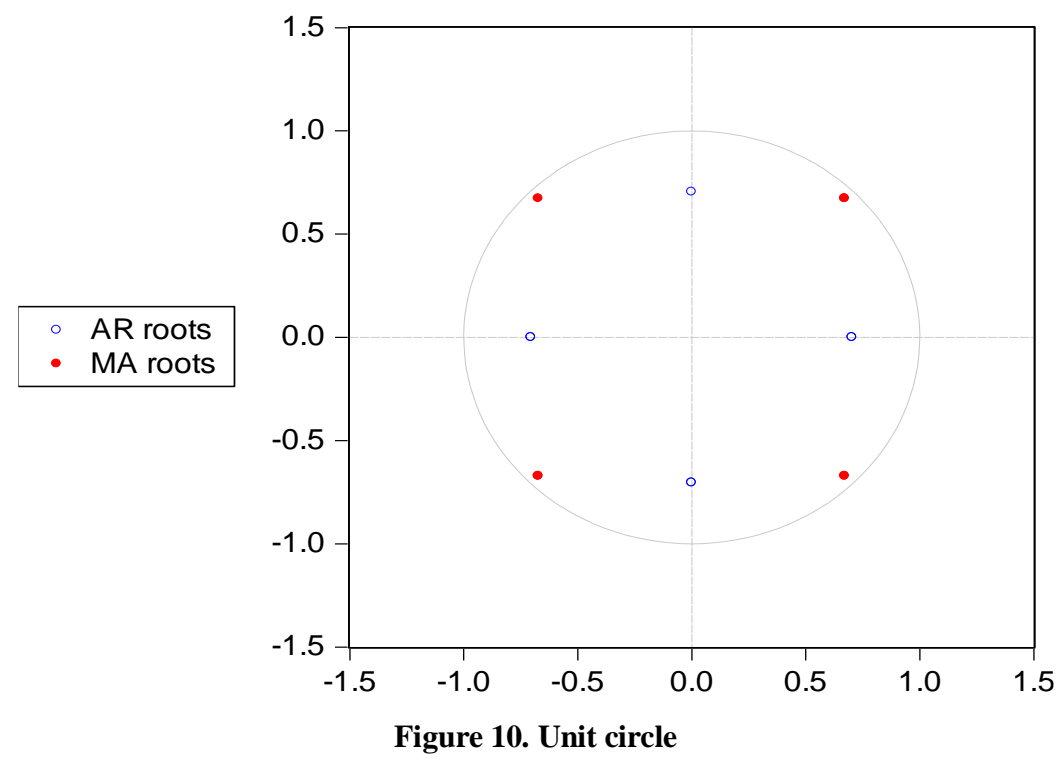

Source: compiled by author.

Any shock to this model i.e. response to one standard deviation innovation turns the series towards equilibrium which is distinctly shown in Figure 11 where shocks are gradually minimised. It implies that the model is stationary where agriculture and allied activities can be treated as negative shocks but other sectors like industry, trade and services are positive shocks. The impulse response function was unable to identify the factors because no variables were included and the method of cointegration and vector error correction model were also excluded here. 


\section{Response to One S.D. Innovation}

Impulse Response \pm 2 S.E.

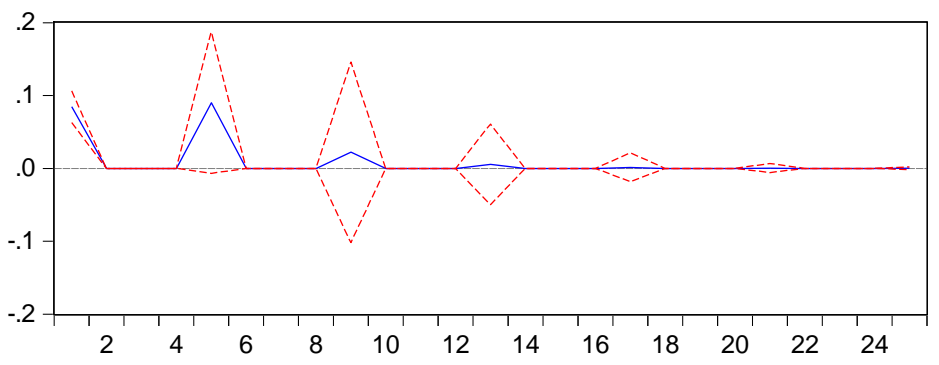

Accumulated Response \pm 2 S.E.

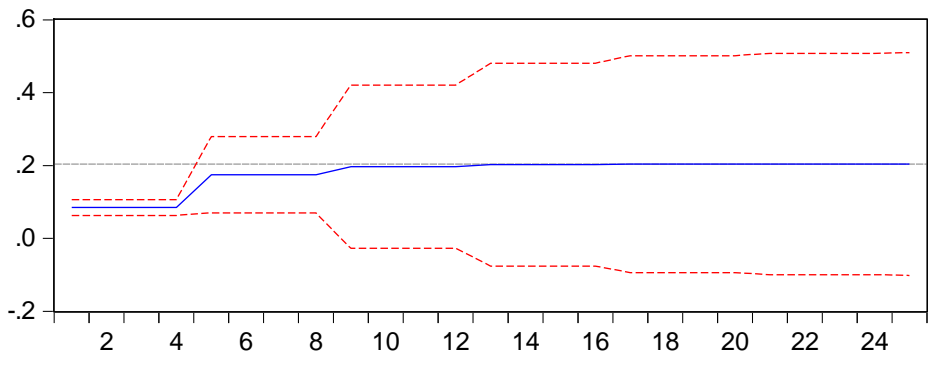

Figure 11. Impulse response function

Source: compiled by author.

Applying ARCH(4) method of Heteroscedasticity test for the forecasting ARIMA(4,0,4) model for 2030 assures that the coefficient of residual squares at lag t-1 is significant at $5 \%$ level but other coefficients of squares of residuals at lag t-2,t-3 and t- 4 were found insignificant and estimated $\mathrm{R}^{2}=0.504$ and $\mathrm{n}=26$, so that $\mathrm{nR}^{2}=13.1173$ which is rejected at null hypothesis of no heteroscedasticity at $5 \%$ significant level which was justified by $\chi^{2}(4)$ test.

$\varepsilon_{t}^{2}=005423+0.8217 \varepsilon_{t-1}^{2}-0.6433 \varepsilon_{t-2}^{2}+0.01301 \varepsilon_{t-3}^{2}-0.1351 \varepsilon_{t-4}^{2}+u_{t}$

$(2.46)^{*}(3.62)^{*}$

$\mathrm{R}^{2}=0.5045, \mathrm{~F}=5.345^{*}, \mathrm{AIC}=-7.345, \mathrm{SC}=-7.103, \mathrm{DW}=1.918, \mathrm{n}=26, \mathrm{nR}^{2}=13.1173$, probability of $\chi^{2}(4)=0.0107$

The existence of unequal variance in the residuals of Hamilton regression filter when pass through ARIMA $(4,0,4)$ model confirmed that the volatility was not vanished completely during cyclical variation of the GDP series of Ukraine in the specified period and even during the period of forecasting up to 2030 because of its structural phenomenon.

\section{Limitations and new scope of research}

The paper should have much more observations for achieving further accuracy of the findings from the models. Even, long period monthly data could reveal additional micro-level analysis of cyclical fluctuations of GDP. The problems of autocorrelation and heteroscedasticity are chief barriers for attaining stationary equilibrium process. The duration of recovery is longer than its duration of downswing. The future research should have enough scope to find the reasons and should formulate the remedies. The clear identification of indicators of positive and negative shocks might be additional exploration of analysis of the model in forthcoming research where cointegration and vector autoregression model would be additional methodology.

\section{The model ensures policy considerations}

It was observed that there were downswing of GDP in every first quarter since 2010 till 2020 which imply that the festive period with severe cold may be reasons of declining GDP of Ukraine where the contributions from agriculture and allied activities, manufacturing, gross capital formation, real estate, transportation and storage had been fallen successively. Even, export and import have declined massively in every first quarter. These 
seasonal variations are structural which is to be reformed through anticyclical fiscal and monetary policy. Substitute economic activities to increase sectoral share in the first quarter have to be formulated through diversification, technological innovations and environmental protections. Changing consumption patterns, service activities, new health care system, and increasing human capital formation might help to catapult value additions from the above stated sectors in Ukraine other than the general macro-economic policies.

\section{Conclusions and remarks}

The paper concludes that the GDP of Ukraine has been increasing at the rate of $3.66 \%$ per quarter during 2010Q1-2020Q1 significantly which was found stable according to CUSUM of squares test and this series consists of four upward structural breaks in 2011Q3,2013Q3, 2015Q3 and 2017Q3 respectively. The decomposition of Hamilton regression filter produces clearly one cycle showing speedy recovery and slowly recessionary trend. Seasonally adjusted series of GDP has marginal difference with residual but its seasonal variation is uniform showing declining in every first quarter of the year which is $v$ shaped. Seasonal variation is tested with the patterns of ACF and PACF during the period. H.P. Filter is rather different from Hamilton filter in terms of both trend and cycle but more or less similar with the asymmetric time varying random walk filter of Christiano and Fitzgerald. ARIMA $(4,0,4)$ forecast model for 2030 is incorporated in Hamilton regression filter and it appeared with stable and stationary model showing cyclical fluctuations of both downswings and upswings although it confronted with heteroscedasticity problem.

Other than the central econometric conclusions obtained from the models, there are many general economic and political reasons too by which cycles were inevitable in Ukraine. Devastation of Donbas had reduced GDP growth rate and index of export up to 2015 and average wage fell down in 2014 and deteriorated in absolute terms in Donetsk and Luhansk where humanitarian crisis was acute. Even, industrial production decreased during 2014-2017 in Donetsk and Luhansk which induced a reduction in employment opportunities there due to devastation in Donbas irrespective of increase in unemployment rate by $9.5 \%$ in 2017 in comparison to 2$2.5 \%$ during 2013-2017 as indicated by ILO (WFP, 2019). On the other hand, IMF assistance by EFF was increased during 2012-2014 which raised debt burden too. Thus, Ukraine may emphasis on recovery packages to rise restoration funds, to issue reconstruction bonds as post war resilience and should give more importance on old value chain and on growth of human capital (Havlik et al,2020). Regional disparity is another constraint which adversely affected seasonal variation of GDP of Ukraine. Thus, for amelioration of regional imbalance, the country should increase investment in rural health care, rural education and infrastructure as preventive measures (Kushnirsky \& Maksymenko, 2016).

Above all, the crux of the problems is the negative contribution of agriculture to GDP growth, rising public debt due to loose fiscal driven policy, failure of target rates of inflation and unemployment, tight monetary policy and so on that are preventing to decrease volatility of seasonal fluctuation of GDP. Last but not the least, it is indeed wise to impose new monetary and fiscal policy including reform measures which should be allied to international economies and institutions that may induce to increase sectoral shares of agriculture and allied activities, manufacturing, transport, real estate , gross capital formation and other macro-economic indicators respectively during the period of downturns in GDP.

\section{References}

1. Baxter, M., \& King, R. G. (1999). Measuring business cycles: Approximate band-pass filters for economic Time Series. Review of Economics and Statistics, 81(4), 575-593. Retrieved from: https://EconPapers.repec.org/ RePEc:tpr:restat:v:81:y:1999:i:4:p:575-593

2. Bhowmik, Debesh. (2020). Cyclical and seasonal patterns of India's GDP growth rate through the eyes of Hamilton and Hodrick Prescott Filter models. Forthcoming.

3. Bjomland, Hilde Christiane. (2000, August). Detrending Methods and Stylized Facts of Business Cycles in Norway-An international Comparison. Empirical Economics,25(3),369-392. https://doi.org/ 10.1007/ s001810000023

4. Bosupeng, Mphs. (2019). Forecasting Tourism Demand: The Hamilton Filter. Annals of Tourism Research,79, 102823. https://doi.org/10.1016/j.annals.2019.102823

5. Box, George., \& Jenkins, Gwilym. (1976). Time Series Analysis, Forecasting and Control. San Francisco: Holden Day. ISBN 10: 0816211043 / ISBN 13: 9780816211043

6. Burns, A.F., \& Mitchell, W.C. (1946). Measuring Business Cycles. New York: National Bureau of Economic Research. Retrived from: https://econpapers.repec.org/RePEc:nbr:nberbk:burn46-1. 
Financial Markets, Institutions and Risks, Volume 4, Issue 3, 2020 ISSN (online) - 2521-1242 ISSN (print) - 2521-1250

7. Christiano, L.J., \& Fitzgerald, T. J. (2003). The band pass filter. International Economic Review,44(2),435-465. Retrieved from: https://EconPapers.repec.org/RePEc:ier:iecrev:v:44:y:2003:i:2:p:435-465

8. Colak, Mehmet Selman., Guney, Ibrahim Ethem., Senol, Ahmet., \& Yilmaz, Muhammad Hasan. (2019). Monitoring and forecasting Cyclical Dynamics in Bank Credits: Evidence from Turkish Banking Sector. Working Papers-1929, Research and Monetary Policy Department, Central Bank of the Republic of Turkey. Retrieved from: https://ideas.repec.org/p/tcb/wpaper/1929.html

9. Cleveland, R.B., Cleveland, W.S., McRac, J.E., \& Terpenning, I. (1990). STL : A Seasonal-Trend Decomposition Procedure Based on Loess. Journal of Official Statistics, 6(1),3-33. Retrived from: http://bit.ly/stl1990

10. Diallo, Ibrahima Amadou. (2018). Hamilton Filter: State module to calculate the Hamilton filter for a Simple Time Series or for a Panel Dataset. Statistical Software Components, s458449. Retrieved from: http://fmwww.bc.edu/reec/bocode/h/hamiltonfilter.ado

11. Dias, Maria Helena Amorosio., \& Dias, Joilson. (2010, May). Measuring the Cyclical component of a Time Series: Proposal of a New Methodology. Brazilian Review of Econometrics, 30(1), 91-122. Retrieved from: http://bibliotecadigital.fgv.br/ojs/index.php/bre/article/download/3503/2211

12. Dolado, Juan J., Sebastian, Miguel., \& Valles, Javier. (1993). Cyclical Patterns of the Spanish Economy. Investigaciones Economicas,17(3),445-473. Retrieved from: https://ideas.repec.org/a/iec/inveco/ v17y1993i3p445-473.html

13. Gali, J. (1999, March). Technology, Employment and the Business Cycle: Do Technology shocks explain Aggregate Fluctuations? American Economic Review,89(1),249-271. Retrieved from: https://www.aeaweb.org/articles?id=10.1257/aer.89.1.249

14. Hamilton, J.D. (1989, March). A New Approach to the economic analysis of non-stationary time series and the business cycle. Econometrica, 57(2),357-384. Retrieved from: https://ideas.repec.org/a/ecm/emetrp/ v57y1989i2p357-84.html

15. Hamilton, J. D. (2018). Why you should never use the Hodrick Prescott Filter. Review of Economics and Statistics, 100(5),831-843. Retrieved from: https://ideas.repec.org/a/tpr/restat/v100y2018i5p831-843.html

16. Havlik, P., Kochnev, A., \& Pindyuk, O. (2020, June). Economic challenges and costs of reintegrating the Donbas region in Ukraine. Research Report 447, WIIW. Retrieved from: https://wiiw.ac.at/economicchallenges-and-costs-of-reintegrating-the-donbas-region-in-ukraine-dlp-5351.pdf

17. Henderson, Robert. (1916). Note on Graduation by Adjusted Average. Transactions of the Actuarial Society of America,17,43-48. Retrieved from: https://rivista-statistica.unibo.it/article/view/3597

18. Hodrick, R.J., \& Prescott, E.C. (1997, February). Post-war US Business Cycles :An Empirical Investigation. Journal of Money, Credit and Banking, 29(1),1-16. Retrieved from: http://www.jstor.org/stable/2953682

19. Hodrick, R, J. (2020, February). An explanation of trend-cycle decomposition methodologies in simulated data. NBER Working Paper-26750. Retrieved from: https://www.nber.org/papers/w26750

20. Kushnirsky, F.I., \& Maksymenko, S.V. (2016, October). Ukraine's regional economic growth and analysis of regional disparity.Working Paper Series-17/00,University of Pittsburgh. Retrieved from: https://www.econ. pitt.edu/sites/default/files/WP\%2017-002.upload.pdf.

21. Lebedeva, L et al. (2019). Estimation of resilience of Ukrainian industry to shock influences: Comparative analysis. EUREKA: Social and Humanities, Number 1,20-34. DOI: 10.21303/2504-5571.2019.00816. Retrieved from: http://eu-jr.eu/social/article/download/816/834

22. Liu, Philip. (2008). The Role of International shocks in Australia's Business Cycle. Research Discussion Paper-RDP2008-08. Reserve Bank of Australia. Retrieved from: https://www.rba.gov.au/publications/ rdp/2008/pdf/rdp2008-08.pdf

23. Pieńkowski, Jerzy. (2020, April). The Impact of Labour Migration on the Ukrainian Economy. EU Discussion Paper 123. doi:10.2765/450169. Retrieved from: https://ec.europa.eu/info/publications/economic-and-financial-affairs-publications_en.

24. Pollock, D. Stephen G. (2018, July). Filters, Waves and Spectra.Econometrics,6,35,1-33. http://doi.org/10.3390/econometrics6030035

25. Prescott, E. (1986). Theory Ahead of Business-Cycle Measurement. Carnegie-Rochester Conference Series on Public Policy,25,11-44. Retrieved from: https://casee.asu.edu/upload/Prescott/1986RBCRERAP-Theory\%20Ahead\% 20of\%20 Business\%20Cycle\%20Measurement.pdf

26. Schuler, Y.S. (2018). On the Cyclical properties of Hamilton's regression filter. Discussion Paper-03, Deutsche Bundesbank. Retrieved from: www.econstor.eu > bitstream 
27. Strzelecki,P. et al.(2020). The contribution of immigration from Ukraine to economic growth in Poland. NBP Working Paper 322.Warsaw. Retrieved from: https://www.nbp.pl/publikacje/materialy i studia/322 en.pdf

28. Tkalenko, Svitlana., \& Glushchenk, Svitlana. (2016).Threats and benefits of exchange rate regimes for Ukraine in terms of European integration. Baltic Journal of Economic Studies,2(2),32-39. Retrieved from: http://www.baltijapublishing.lv/index.php/issue/article/download/77/82/

29. Toledo Neto, C.C. (2004). Ciclos do Produts Brasileiro Decomposicao e Analise em "Tempo Real". PhD Thesis. FEA-USP. Retrieved from: http://bibliotecadigital.fgv.br/ojs/index. php/bre/article/download/ $3503 / 2211$

30. World Food Programme. (2018). Ukraine Socio-Economic and Market Review 2018. Retrieved from: https://docs.wfp.org/api/documents/WFP-0000104176/download/

31. Yogo, M. (2008). Measuring business cycles: A Wavelet analysis of economic time series. Economic Letters, 100(2), 208-212. Retrieved from: http://www.sciencedirect.com/science/article/pii/S0165$1765(08) 00012-8$

32. Zalgiryte, Lina., \& Giziene, Vilda. (2014). The analysis of trends in GDP and Cyclical nature of GDP changes in Baltic States. Social and Behavioural Science,156,371-375. Retrieved from: https://cyberleninka.org/article/n/1355134

33. Zarnowitz, Victor., \& Ozyildirim, Ataman. (2002, January). Time Series Decomposition and Measurement of Business Cycles, Trends and Growth Cycles. NBER, Working Paper-w8736. Retrieved from: https://ideas.repec.org/p/nbr/nberwo/8736.html

\section{Appendix-1}

Table 1. Data of Quarterly GDP at current prices in million UAH of Ukraine

\begin{tabular}{|c|c|c|c|c|c|c|c|c|c|}
\hline 2010Q1 & 2010Q2 & 2010Q3 & 2010Q4 & 2011Q1 & $2011 \mathrm{Q} 2$ & 2011Q3 & 2011Q4 & 2012Q1 & 2012Q2 \\
\hline 217074 & 255545 & 300446 & 306281 & 258591 & 310277 & 368488 & 362635 & 292324 & 346005 \\
\hline 2012Q3 & $2012 Q 4$ & 2013Q1 & 2013Q2 & 2013Q3 & $2013 Q 4$ & 2014Q1 & 2014Q2 & 2014Q3 & 2014Q4 \\
\hline 387109 & 379231 & 303753 & 354814 & 398000 & 408631 & 316905 & 382391 & 440476 & 447143 \\
\hline 2015Q1 & 2015Q2 & 2015Q3 & $2015 \mathrm{Q} 4$ & 2016Q1 & 2016Q2 & 2016Q3 & 2016Q4 & 2017Q1 & 2017Q2 \\
\hline 375991 & 456715 & 566997 & 588841 & 455298 & 535701 & 671456 & 722912 & 592523 & 665233 \\
\hline 2017Q3 & $2017 Q 4$ & 2018Q1 & 2018Q2 & 2018Q3 & 2018Q4 & 2019Q1 & 2019Q2 & 2019Q3 & 2019Q4 \\
\hline 834287 & 891839 & 705977 & 810174 & 994810 & 1049635 & 815123 & 932677 & 1111862 & 1114902 \\
\hline
\end{tabular}

